\title{
Isolation and Identification of Mycorrhizosphere Bacteria and Their Antagonistic Effects Towards Ganoderma boninense in vitro
}

\author{
YENNI BAKHTIAR ${ }^{1,2 *}$, SUDIRMAN YAHYA ${ }^{1}$, WAHONO SUMARYONO ${ }^{2}$, MEITY SURADJI SINAGA $^{3}$, \\ SRI WILARSO BUDI ${ }^{4}$, AND TEUKU TAJUDDIN ${ }^{2}$ \\ ${ }^{1}$ Department of Agronomy, Faculty of Agriculture, Institut Pertanian Bogor, Darmaga Campus, Bogor 16680, Indonesia; \\ ${ }^{2}$ Center of Biotechnology, Badan Pengkajian dan Penerapan Teknologi, Gedung 630 Kawasan Puspiptek Serpong, \\ Tangerang Selatan 15314, Indonesia; ${ }^{3}$ Department of Plant Protection, Faculty of Agriculture and \\ ${ }^{4}$ Department of Silviculture, Faculty of Forestry, Institut Pertanian Bogor, Darmaga Campus, Bogor 16680, Indonesia
}

\begin{abstract}
Basal stem rot caused by Ganoderma boninense is the most serious disease of oil palm (Elaeis guineensis) in Indonesia and it has caused major loss in palm oil production. Mycorrhizosphere bacteria offer possible advantages as biocontrol agents as they live and proliferate together with arbuscular mycorrhizal fungi, which have an ability to increase plant resistance against pathogens. A study was conducted to isolate mycorrhizosphere bacteria from spores of arbuscular mycorrhizal fungi and test their antagonistic effects against G. boninense in vitro. All bacterial isolates were identified based on $16 \mathrm{~S}$ rDNA analysis and it revealed that eleven out of twenty mycorrhizosphere bacteria isolated were related to Bacillus with similarity ranging from 97 to $100 \%$, whereas other isolates were identified as Pseudomonas, Streptomyces, Kocuria, Enterobacter, Brevundimonas, and Alcaligenes with similarities ranging from 96 to $100 \%$. Fourteen out of twenty mycorrhizosphere bacteria showed a varying degree of inhibition towards the growth of $G$. boninense in vitro. Of these, isolate B10 (closely related to Bacillus subtilis ZJ06) showed the highest inhibitory effect followed by B17 (closely related to Bacillus subtilis N43). Therefore, these bacteria have a potential to be used as biocontrol agents to control basal stem rot disease caused by G. boninense in oil palm.
\end{abstract}

Key words: mycorrhizosphere bacteria, arbuscular mycorrhizal fungi, antagonistic effects, Ganoderma boninense

Oil palm (Elaeis guineensis) is one of the most important crops in Indonesia. In 2008, Indonesia exported 14.6 million tons of crude palm oil worthing USD 12.659 million (Dharsono 2009). However, some fungal diseases, especially basal stem rot (BSR) disease caused by Ganoderma boninense have reduced the annual production of oil palm in South East Asia (Treu 1998). Until now, there is no known cure for BSR and this has led to dramatic yield losses in palm oil production (Sundram et al. 2008). Control of BSR through the use of chemicals in the field has not been proven successful (Sapak et al. 2008). The use of antagonistic microbes to control the disease as a mean of biological control can be an alternative approach to control the disease.

Arbuscular mycorrhizal fungi (AMF) are known for their beneficial effects on plants including their ability to promote the growth of plants. (Blal et al. 1990). The ability of AMF to promote plant growth can be attributed to protection against root pathogens and production of substances affecting plant growth (Phosri et al. 2010). Hashim (2004) reported that inoculation of oil palm seedlings with AMF suppressed BSR disease incidence and prolonged incubation time required for Ganoderma to cause infection in the seedlings.

Arbuscular mycorrhizal fungi coexist with other soil organisms in the rhizosphere (Bharadwaj et al. 2008). Bacteria associated with AMF are defined as mycorrhizosphere bacteria (Artursson et al. 2006). Garbaye (1991) defined mycorrhizosphere as a rhizosphere of a root infected by a mycorrhizal fungus. Garbaye stated that as the fungus uses some of root exudates and modifies root functions, microbial communities in the mycorrhizosphere

*Corresponding author, Phone/Fax: +62-21-7563120/7560208; Email: ybakhtia@hotmail.com differ from those in the rhizosphere and in the soil. It is considered that changes in microbial populations in the mycorrhizosphere could be involved in plant disease suppression. The mechanisms involved in disease suppresion could be mainly due to induction of the host defence mechanisms such as the formation of structural barriers, lignification of cell walls, and the production of antifungal metabolites to slow down the progress of infection and improve plant growth and vigor (Sapak et al. 2008).

Isolation and identification mycorrhizosphere bacteria from rhizosphere of uninfected oil palm surrounded by oil palm heavily infected by $G$. boninense could be useful as a preliminary study of biocontrol of BSR in oil palm. We assumed that the absence of Ganoderma infection in the plant that is surrounded by infected plants can be attributed to the presence of microbes in the rhizosphere of the plant that trigger resistance to Ganoderma attack. Thus, this region could be a good source of mycorrhizosphere bacteria. The objectives of this study were to isolate and identify mycorrhizosphere bacteria from spores of AMF in the rhizosphere of oil palm that showed antagonistic effects against $G$. boninense.

\section{MATERIALS AND METHODS}

Isolation of Arbuscular Mycorrhiza Fungal Spores. Spores of AMF were isolated from rhizosphere of oil palm plantings in the Aek Pancur Plantation belonging to the Indonesian Oil Palm Research Institute, North Sumatera, during September 2006. Soil samples were analysed to determine nutrient contents at the Soil Research Institute, Bogor. Spores of AMF were isolated from $500 \mathrm{~g}$ of soil samples using a decanting-sieving-method (Brundrett et al. 1994). Spores were counted using a dissecting microscope and the spores were kept for later use for bacterial isolation. 
Isolation of Mycorrhizosphere Bacteria. Mycorrhizosphere bacteria were isolated from spores of AMF using a method described by Reimann (2005). Collected spores were crushed using sterile needles and transferred to Petri dishes containing nutrient agar (NA) with concentrations of $1 \times, 10 \times$, and $100 \times$; tryptic soy agar (TSA) with concentrations of $1 \times, 10 \times, 100 \times$; and Pseudomonas agar base $(\mathrm{PAB})$ at $1 \times$ concentration. All the crushed spores were put on the surface of the agar media and then incubated for $48 \mathrm{~h}$ at $20^{\circ} \mathrm{C}$. All bacteria that grew on the media were transferred to another agar media until single colonies were isolated. All single colonies were transferred to agar slants and stored at $4{ }^{\circ} \mathrm{C}$. Morphological examination was then conducted on these colonies.

DNA Extraction. Total DNA of the bacteria was extracted using an Instagene Matrix Kit (BioRad). One-dayold bacterial colonies on slant agar were added with $1.0 \mathrm{~mL}$ of sterile water in order to get suspension of bacteria. The bacterial suspension was transferred to $1.5 \mathrm{~mL}$ eppendorf tubes, suspended with sterile water and centrifuged at 10000 $\times \mathrm{g}$ for $1 \mathrm{~min}$. The supernatants were decanted and the pellets were resuspended with $200 \mu \mathrm{L}$ Instagene Matrix. The bacterial suspension was then incubated at $56^{\circ} \mathrm{C}$ for $15-30$ min on a heat block, vortexed with high speed for $10 \mathrm{sec}$ and returned to the heat block, incubated at $100^{\circ} \mathrm{C}$ for $8 \mathrm{~min}$, and vortexed again with high speed for $10 \mathrm{sec}$, then repelleted at $10000 \times \mathrm{g}$ for $2-3 \mathrm{sec}$. The supernatant containing the DNA was then stored at $-20^{\circ} \mathrm{C}$.

Polymerase Chain Reaction. Five $\mu$ L of DNA template was mixed with $45 \mu \mathrm{L}$ PCR solution containing $5 \mu \mathrm{L}$ of 25 $\mathrm{mM} \mathrm{MgCl} 2,4 \mu \mathrm{L}$ of $2.5 \mathrm{mM}$ dNTP mix, $5 \mu \mathrm{L}$ of $10 \mathrm{x}$ PCR buffer, $0.25 \mu \mathrm{LLA}$ tag, $2 \mu \mathrm{L}$ of $10 \mathrm{M}$ Primer $8 \mathrm{~F}, 2 \mu \mathrm{L}$ of $10 \mathrm{M}$ Primer $1492 \mathrm{R}$, and $26.75 \mu \mathrm{L} \mathrm{ddH}_{2} \mathrm{O}$ in a total final reaction volume of $50 \mu \mathrm{L}$. Amplification of the peptide synthetase was carried out using the universal primers $8 \mathrm{~F}\left(5^{\prime}\right.$ GGTTACCTTGTTACGACTT 3') and 1492R (5' AGAGTTTGATCCTGGCTCAG 3') from AlphaDNA (Canada). PCR was carried out as follows: initial denaturation at $96^{\circ} \mathrm{C}$ for $3 \mathrm{~min}, 30$ cycles consisting of denaturation at $96^{\circ} \mathrm{C}$ for $45 \mathrm{sec}$, annealing at $56^{\circ} \mathrm{C}$ for $30 \mathrm{sec}$, and elongation at $72^{\circ} \mathrm{C}$ for $2 \mathrm{~min}$. The reaction was completed by a final extension at $72^{\circ} \mathrm{C}$ for $7 \mathrm{~min}$. PCR products were then analyzed by electrophoresis in a $0.8 \%$ $(\mathrm{w} / \mathrm{v})$ agarose gels in $1 \mathrm{x}$ TAE running buffer at $100 \mathrm{~V}$ for 30 min. Gels were visualized under a UV illuminator and visible DNA bands that corresponded to the expected size were cut and purified using a Gene Aid Kit.

DNA Sequencing. The primers used for cycle sequencing were 765R (5' CTGTTTGCTCCCCACGTTTC 3') and 1141R (5' GGGTTGCGCTCGTTGC 3') from AlphaDNA(Canada). Cycle sequencing solution contains the following components: $2 \mu \mathrm{L}$ of $5 \mathrm{x}$ sequencing buffer, $2 \mu \mathrm{L}$ primer mix (765 R and 1141R), $4 \mu \mathrm{L}$ big dye $\mathrm{V} 3.1,4 \mu \mathrm{L}$ DNA template and $8 \mu \mathrm{L} \mathrm{H}_{2} \mathrm{O}$ to give a final reaction mixture of $20 \mu \mathrm{L}$. The cycle sequencing was performed as follows: initial denaturation at $96^{\circ} \mathrm{C}$ for $3 \mathrm{~min}, 25$ reaction cycles
The cycle sequencing products were then purified prior to reading the DNA sequence. The resulting DNA from cycle sequencing was first purified by precipitating the DNA using ethanol, sodium acetate, and EDTA followed by centrifugation and rinsing the pelllets with $70 \%$ ethanol. Purified DNA was resuspended in $12 \mu \mathrm{L}$ of $\mathrm{ddH}_{2} \mathrm{O}$ prior to reading the DNA sequence using Genetic Analyzer 3130 (Applied Biosystems, USA). The DNA contigs were assembled using ATGC program that connects the 765R and $1141 \mathrm{R}$ primers. The resulting sequences were compared with DNA sequences available in the GenBank database of NCBI using BLAST program.

Phylogenetic Tree Construction. Alignment of $16 \mathrm{~S}$ rDNA sequences was performed using ClustalX. The phylogenetic tree was constructed by comparing 16S rDNA sequences of twenty isolated mycorrhizosphere bacteria with $16 \mathrm{~S}$ rDNA sequences of twenty bacteria from GeneBank DNA database and then visualized using Tree View 1.6.6. The phylogenetic relationship was revealed by neighbor-joining analysis combined with bootstrap analysis from 100 replicates.

Antagonistic Effects of Mycorrhizosphere Bacteria towards Ganoderma boninense. All mycorrhizosphere bacteria were screened in vitro for their ability to inhibit the growth of $G$. boninense by measuring area of clearing zones formed surrounding the bacterial colonies. One-mLaliquots of each bacterial suspension was inoculated into 50 $\mathrm{mL}$ nutrient broth, tryptic soy broth and Pseudomonas broth. The bacterial cultures were incubated in a shaking incubator (150 rpm) at $28^{\circ} \mathrm{C}$ for $12 \mathrm{~h}$.

Isolates of $G$. boninense were inoculated onto potato dextrose agar (PDA) and spread all over the agar surface using sterile cotton buds. Four sterile paper discs $(6.0 \mathrm{~mm}$ diameter) were used for antagonistic activity test. Each paper disc was dipped with bacterial suspension, placed on the agar surface, and then put in a refrigerator at $4^{\circ} \mathrm{C}$ for $1.5 \mathrm{~h}$ to allow absorbtion of the bacterial suspension into the media. The cultures were then incubated at $28^{\circ} \mathrm{C}$ for three days. The antagonistic effects of the bacteria were evaluated by measuring the area of the clearing zones.

A completely randomized design with two factors was used to analyze the data. The first factor was the type of bacterial inoculum. The second factor was the volume of bacterial suspension inoculated onto the media. Discs that dipped in media without bacteria was defined as a negative control, while inoculation with antifungal chloramin-T 2\% was used as a positive control. Each treatment was replicated 4 times.

\section{RESULTS}

Isolation and Identification of Mycorrhizosphere Bacteria. A total of 56 mycorrhizosphere bacteria were isolated from spores of AMF. There were 24 isolates that grew on NA, 29 isolates on TSA, and 3 isolates on PAB. 
Colonies of the mycorrhizosphere bacteria were selected based on their morphological characteristics such as color and shape of the colonies. The results showed that from 56 isolates of mycorrhizosphere bacteria, there were 20 isolates that showed different morphological characteristics (Table 1). All of the 20 mycorrhizosphere bacteria were then identified based on their 16S rDNA. Phylogenetic analysis of $16 \mathrm{~S}$ rDNA showed that the mycorrhizosphere bacteria were dominated by Bacillus spp. (11 out of 20 isolates: B2, B4, B5, B8, B10, B11, B13, B14, B15, B16, and $\mathrm{B} 17)$. The other groups belonged to the genera Streptomyces (B1), Enterobacter (B6), Brevundimonas (B9), Kocuria (B3), Alcaligenes (B7, B12, and B18) and Pseudomonas (B19 and B20) (Table 2). Curiously, even though isolate B14 and B16 were closely related to Bacillus thuringiensis AE1.16 with $100 \%$ similarity, the color of their colonies was very different on NA media at the same age (Fig 1).

Antagonistic Effects of Mycorrhizosphere Bacteria against Ganoderma boninense. Among the 20 isolates of mycorrhizosphere bacteria, 14 isolates (B3, B4, B5, B6, B7, B8, B9, B10, B11, B12, B14, B16, B17, and B19) showed an ability to inhibit the growth of $G$. boninense in vitro as indicated by clearing zones formed around the bacterial colonies (Fig 3). Isolate B10 (closely related to Bacillus subtilis ZJ06) gave the largest clearing zone $\left(52.84 \mathrm{~mm}^{2}\right)$ followed by B17 isolate (closely related to B. subtilis N43) with clearing zone area of $44.80 \mathrm{~mm}^{2}$. In contrast, six other mycorrhizosphere bacteria isolates (B1, B2, B13, B15, B18, and B20) did not exhibit any inhibition to the growth of G. boninense.

Table 1 Morphological characteristics of selected mycorrhizosphere bacteria isolated from spores of arbuscular mycorrhizal fungi

\begin{tabular}{lll}
\hline Isolate code & $\begin{array}{l}\text { Media and } \\
\text { concentration }\end{array}$ & $\begin{array}{l}\text { Color and form of colonies on } \\
\text { agar plate }\end{array}$ \\
\hline B1 & NA 1x & Light brown, undulate \\
B2 & TSA 1/10x & $\begin{array}{l}\text { White, undulate } \\
\text { B3 }\end{array}$ \\
NA 1x & Yellow, entire (smooth) \\
B4 & NA 1x & Yellow-cream, filiform \\
B5 & NA 1/10x & White, filiform \\
B6 & TSA 1/10x & Creamy-white, entire \\
B7 & TSA 1x & Cream-brownish, lobate \\
B8 & NA 1x & Creamy-white, entire \\
B9 & NA 1/100 x & Pink, entire \\
B10 & TSA 1x & Creamy-white, lobate \\
B11 & NA 1x & White, entire \\
B12 & TSA 1x & Cream, lobate \\
B13 & TSA 1x & Brown, lobate \\
B14 & TSA 1x & Yellow-cream, lobate \\
B15 & NA 1x & Creamy-white, entire \\
B16 & TSA 1/10x & Red-white, undulate \\
B17 & NA 1x & White, filiform \\
B18 & TSA 1x & Brown, undulate \\
B19 & PAB 1x & Orange to bright red-yellow, entire \\
B20 & PAB 1x & Orange to bright red-yellow, entire \\
\hline & & \\
\hline
\end{tabular}

Table 2 Identification of selected mycorrhizosphere bacteria based on their $16 \mathrm{~S}$ rDNA.

\begin{tabular}{lllc}
\hline $\begin{array}{l}\text { Isolate } \\
\text { code }\end{array}$ & Bacterial strains & $\begin{array}{l}\text { Accession } \\
\text { number }\end{array}$ & $\begin{array}{c}\text { Homology } \\
(\%)\end{array}$ \\
\hline B1 & Streptomyces sp. FXJ1.297 & FJ754492.1 & 96 \\
B2 & Bacillus sp. TDSAS2-16 & GQ284549.1 & 98 \\
B3 & Kocuria sp. 10-4DEP & GQ203109.1 & 99 \\
B4 & Bacillus subtilis N43 & GQ465935.1 & 97 \\
B5 & Bacillus thuringiensis CCM11B & FN433030.1 & 100 \\
B6 & Enterobacter sp. JS-48 & GQ280118.1 & 97 \\
B7 & Alcaligenes faecalis AE1.16 & GQ284565.1 & 100 \\
B8 & Bacillus pumilus CrK08 & GQ503326.1 & 100 \\
B9 & Brevundimonas sp. ZF 12 & GQ891673.1 & 100 \\
B10 & Bacillus subtilis ZJ06 & EU266071.1 & 100 \\
B11 & Bacillus clausii CSB15 & FJ189790.1 & 99 \\
B12 & Alcaligenes faecalis AE1.16 & GQ284565.1 & 100 \\
B13 & Bacillus sp. AHE.1 & AY485275.1 & 99 \\
B14 & Bacillus thuringiensis CCM11B & FN433030.1 & 100 \\
B15 & Bacillus pumilus CrK08 & GQ503326.1 & 100 \\
B16 & Bacillus thuringiensis CCM11B & FN433030.1 & 100 \\
B17 & Bacillus subtilis N43 & GQ465935.1 & 97 \\
B18 & Alcaligenes sp. F78 & EU443097.1 & 98 \\
B19 & Pseudomonas stutzeri TSWCW11 & GQ284458.1 & 99 \\
B20 & Pseudomonas stutzeri TSWCW19 & GQ284464.1 & 100 \\
\hline & & & \\
\hline
\end{tabular}
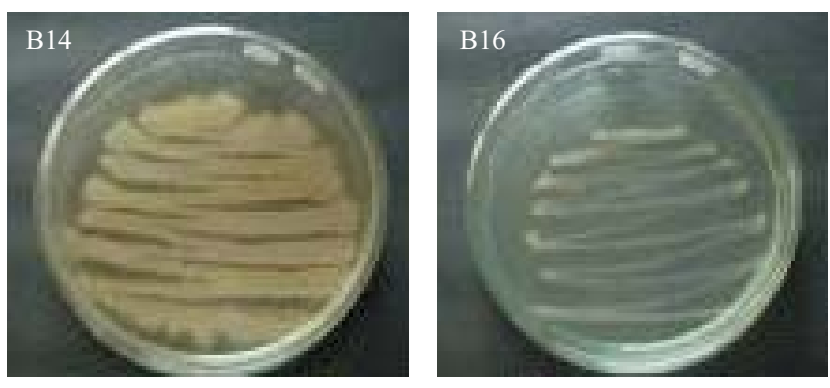

Fig 1 Two isolates of mycorrhizosphere bacteria (B14 and B16) were closely related to Bacillus thuringiensis AE1.16 with $100 \%$ similarity but their colonies grown on nutrient agar were different at the same age.

\section{DISCUSSION}

The present study showed a possibility that mycorrhizosphere bacteria isolated from spores of AMF can be exploited as biological control agents towards $G$. boninense. Bacillus spp. and related genera, which are common soil bacteria, have been identified as potential biological control agents towards pathogens (Ferreira et al. 1991). In this study, the majority (11 out of 20 isolates) of the isolated mycorrhizosphere bacteria were Bacillus sp. This finding was in line with Xavier and Germida (2003) who found that around 80 to $92 \%$ of bacteria isolated from Glomus clarum NT4 spores were endospore-forming Bacillus spp. Mahaffee and Kloepper (1997) also reported that Bacillus sp. is the dominant bacteria found in the rhizosphere due to their versatile physiological ability with 


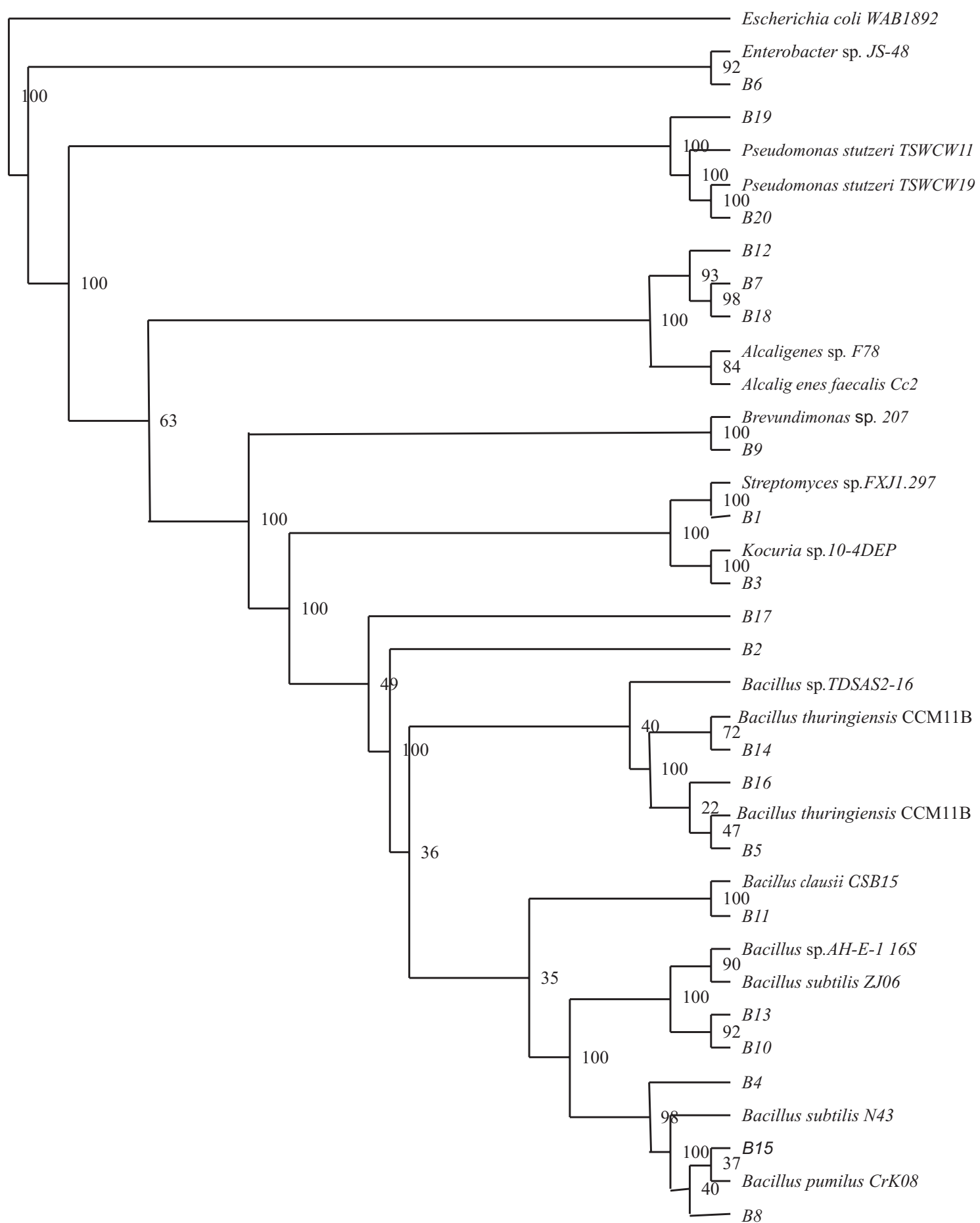

Fig 2 Dendrogram of selected mycorrhizosphere bacteria isolated from spores of arbuscular mycorrhizal fungi in the rhizosphere of oil palm. Eleven out of twenty isolates belong to the genera of Bacillus.

respect to heat, acidity and salinity tolerance. In this study, most of the mycorrhizosphere bacteria, including Bacillus sp. were Gram positive. Artursson et al. (2005) reported that Gram positive bacteria may be more commonly associated with AMF than Gram negative bacteria. Andrade et al. (1997) also reported that genera Arthrobacter and Bacillus were most frequent in the hyposphere, the area of soil surrounding individual AMF hyphae.

In this study, we found some isolates that are homologous based on their 16S rDNA showed different color on NA medium at the same age. The identification of bacteria based on $16 \mathrm{~S}$ rDNA is effective to characterize the relationship between species. We assume that these isolates are located in different sub-species but need further studies to prove it such as using DNA markers at different loci of ribosomal DNA regions. Fox et al. (1992) stated that effective identity of $16 \mathrm{~S} \mathrm{rRNA}$ sequences is not necessarily a sufficient criterion to guarantee species identity. Thus, even though 16S rRNA sequences can be used routinely to differentiate and find out relationships between genera and 


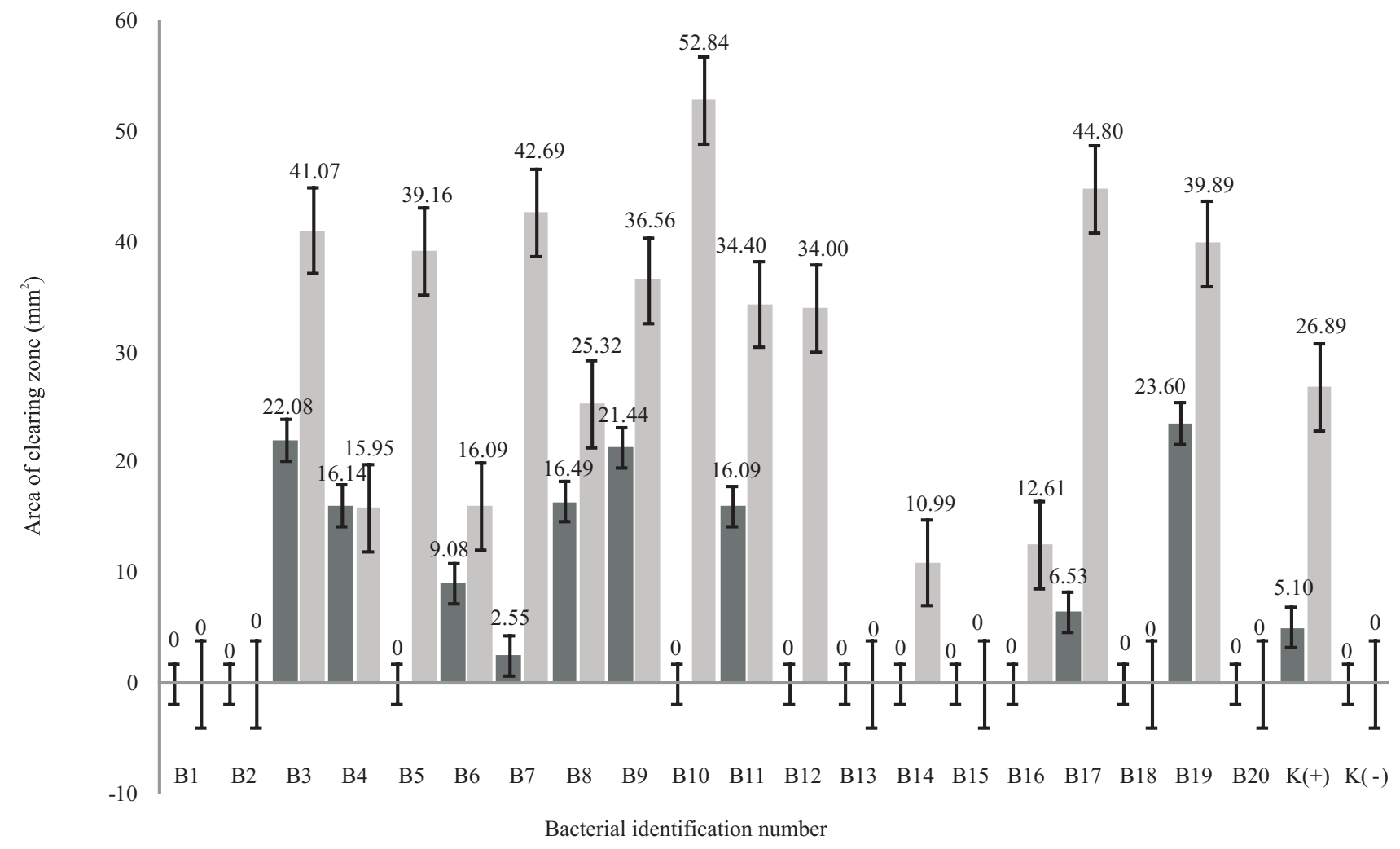

Fig 3 Area of clearing zone as an indication of inhibitory effects of mycorrhizosphere bacteria against the growth of Ganoderma boninense in vitro. Chloramin-T $2 \%(\mathrm{w} / \mathrm{v})$ was used as positive control $\mathrm{K}(+)$ whereas liquid medium without bacterial cells was used as negative control $\mathrm{K}(-)$. B10 isolate gave the largest clearing zone $\left(52.84 \mathrm{~mm}^{2}\right)$ followed by B17 isolate $\left(44.80 \mathrm{~mm}^{2}\right)$. $\square, 10 \mu \mathrm{L}$ of bacterial suspension. $\square, 20 \mu \mathrm{L}$ of bacterial suspension.

well-resolved species, very recently different species may not be recognizable.

The appropriateness of nutrients in nutrient-rich media such as NA and TSA to support the growth of mycorrhizosphere bacteria was investigated. Both media are known to support the growth of a large variety of bacteria. Some bacteria might require smaller amount of nutrients than others. Thus, in this study, different concentrations of the media resulted in variations on the growth of bacteria. Pseudomonas agar base is known as a selective medium and it only encourages Pseudomonas bacterial growth on the medium. There were only two mycorrhizosphere bacteria that grew on this medium.

Two isolates of mycorrhizosphere bacteria B10 and B17 showed the highest antagonistic effects against pathogenic fungi $G$. boninense in vitro as indicated by the most prominent clearing zones observed around colonies of these bacteria. Budi et al. (1999) found that $12.5 \%$ of all bacteria isolated from mycorrhizosphere showed antagonistic effects towards various soilborne pathogens in vitro. They also suggested that mycorrhizosphere may be rich in plant health promoting rhizobacteria (PHPR). Among PHPR, Pseudomonas spp. and Bacillus spp. appear to have the greatest potential as biocontrol agents because they are dominant in the rhizosphere and have the ability to compete with pathogens to improve plant health (Mahaffee and Kloepper 1997). Biocontrol activity occuring in soils with
AMF is linked to associated bacteria (Cruz et al. 2008). There is a large number of publications that reported the potential use of $B$. subtilis as biocontrol agents against pathogenic fungi and bacteria (Ferreira et al. 1991; Leelasuphakul et al. 2008; Velmurugan et al. 2009). A study by Nalisha et al. (2006) found that B. subtilis produced bioactive compounds that are active as antifungal agents against plant pathogenic fungi, Sclerotium rolfsii. A number of B. subtilis strains suppressed the growth of several pathogenic fungi by producing antifungal substances such as iturin A, a group of similar cyclic lipopeptides (Gong et al. 2006); surfactin (Souto et al. 2004); and amicoumacin (Pinchuk et al. 2002).

Bacillus spp. are appealing candidates for biocontrol agents because they produce endospores that are tolerant to heat and desiccation (Weller 1988). Choudary et al. (2009) stated that certain strains of spore-forming Bacillus spp. can elicit induced systemic resistance (ISR) that results in resistance to a broad range of pathogens. Other bacteria such as Enterobacter, Streptomyces have been shown to effectively control diseases caused by soilborne pathogens (Chernin et al. 1995; Singh et al. 1999). In this study, isolate B10 (B. subtilis ZJ06) has a potential to be used as a biocontrol agent against $G$. boninense. There are several possible mechanisms underlying the antagonistic effects of these bacteria towards the growth of $G$. boninense. Such mechanisms are production of antifungal compounds, antagonism through antibiosis and cell wall breakdown by 
cell-wall-degrading enzymes. It still requires further investigations to determine the mechanism involved in inhibition of $G$. boninense by these bacteria. The production of antifungal compound pyrrolnitrin produced by Pseudomonas showed an antagonistic effect against Rhizoctonia solani (Ligon et al. 2000). Siderophores that transport irons into bacterial cells are able to sequester iron (III), thus reducing iron availability to the pathogen (Yang and Crowley 2000). Some bacteria are able to produce lytic enzymes that can lead to degradation of pathogen cell walls (Singh et al. 1999). The basis of antibiosis as a biocontrol mechanism of PHPR has been increasingly better understood over the past two decades. Several studies found a variety of antibiotics that have been identified, including compounds such as oligomycin A, kanosamine, zwittermicin A and xanthobaccin produced by Bacillus, Streptomyces, and Stenotrophomonas spp. that were acted as biocontrol agents towards plant pathogenic fungi (Milner et al. 1995; Milner et al. 1996; Nakayama et al. 1999; Kim et al. 1999; Raaijmakers 2002). Further study is required to investigate the mechanisms of antagonistic of the mycorrhizosphere isolates towards $G$. boninense.

Combination of AMF and mycorrhizosphere bacteria with different mode of actions might strengthen the efficacy of these potential biocontrol agents towards pathogenic fungi rather than a single biocontrol agent. Whether AMF could be used as biocontrol agents practically, or possibly function as vectors for associated bacteria with biocontrol properties, remains to be explored. Based on the findings of this study, it can be concluded that mycorrhizosphere bacteria isolated from AMF spores can be used as antagonistic agents towards pathogenic fungi $G$. boninense, a causal agent of BSR disease in oil palm. Further study is needed to investigate possible mechanisms involved in the antagonism of the mycorrhizosphere bacteria towards the growth of $G$. boninense in vitro and in vivo.

\section{REFERENCES}

Andrade G, Mihara KL, Linderman RG, Bethlenfalvay GJ. 1998. Soil aggregation status and rhizobacteria in the mycorrhizosphere. Plant Soil 202:89-96.

Artursson V, Finlay RD, Jansson JK. 2005. Combined bromodeoxyuridine immunocapture and terminal restriction fragment length polymorphism analysis highlights differences in the active soil bacterial metagenome due to Glomus mosseae inoculation or plant species. Environ Microbiol 7:1952-66.

Artursson V, Finlay RD, Jansson JK. 2006. Interactions between arbuscular mycorrhizal fungi and bacteria and their potential for stimulating plant growth. Environ Microbiol 8:1-10.

Bharawadj DP, Lundquist PO, Alstrom S. 2008. Arbuscular mycorrhizal fungal spore-associated bacteria affect mycorrhizal colonization, plant growth and potato pathogens. Soil Biol Biochem 40:2494-501.

Blal B, Morel C, Gianinazzi-Pearson V, Fardeau C, Gianinazzi S. 1990. Influence of vesicular-arbuscular mycorrhizae on phosphate fertilizer efficiency in two tropical acid soils planted with micropropagated oil palm(Elaeis guineensis). Biol Fertil Soils 9:43-8.

Brundrett MC, Melville L, Peterson L. 1994. Practical methods in mycorrhiza research. Toronto: Mycologue Publ.

Budi SW, Van Tuinen D, Martinotti G, Gianinazzi S. 1999. Isolation from the Sorghum bicolor mycorrhizosphere of a bacterium compatible with arbuscular mycorrhiza development and antagonistic towards soil borne fungal pathogens. Appl Environ Microbiol 65:5148-50
Chernin L, Ismailov Z, Haran S, Chet I. 1995. Chitinolytic Enterobacter agglomerans antagonistic to fungal plant pathogens. Appl Environ Microbiol 61:1720-6.

Choudhary DK, Johri BN. 2009. Interactions of Bacillus spp. and plantswith special reference to induced systemic resistance (ISR). Microbiol Res 164:493-513.

Cruz AF, Horii S, Ochiai A, Yasuda A, Ishii A. 2008. Isolation and analysis of bacteria associated with spores of Gigaspora margarita. J Appl Microbiol 104:1711-7.

Dharsono D. 2009. Development of palm oil export \& revenue. Planters 1:26-8.

Ferreira JHS, Matthee FN, Thomas AC. 1991. Biological control of Euthypa lata on grapevine by an antagonistic strain of Bacillus subtilis. Phytopathol 81:283-7.

Fox GE, Jeffrey DW, Peter JJr. 1992. How close is close: 16S rRNA sequence identity may not be sufficient to guarantee species identity. Int J Syst Bacteriol 42:166-70.

Garbaye J. 1991. Biological interaction in the mycorrhizosphere. Experientia 47:370-5.

Gardemann JW, Nicolson TH. 1963. Spores of Mycorrhizal Endogone species extracted from soil by wet sieving and decanting. Trans $\mathrm{Br}$ Mycol Soc 46:235-44.

Gong M, Wang JD, Zhang J, Yang H, Lu XF, Pei Y, Cheng JQ. 2006. Study of the antifungal ability of Bacillus subtilis strain PY-1 in vitro and identification of its antifungal substance (iturin A). Acta Biochim et Biophys Sin 38:233-240.

Hashim A. 2004. Ganoderma versus mycorrhiza. Palmas 25:21-6.

Kim BS, Moon SS, Hwang BK. 1999. Isolation, identification and antifungal activity of a macrolide antibiotic, oligomycin A, produced by Streptomyces libani. Can J Bot 77:850-8.

Leelasuphakul W, Hemmanee P, Chuenchitt S. 2008. Growth inhibitory properties of Bacillus subtilis strains and their metabolites against the green mold pathogen (Penicillium digitatum Sacc.) of citrus fruit. Postharvest Biol Technol 48:113-21.

Ligon JM, Hill DS, Hammer PE, Torkewitz NR, Hofmann D, Kempf HJ, Van Pee KH. 2000. Natural products antifungal activity from Pseudomonas biocontrol bacteria. Pest Manag Sci 56:688-95.

Mahafee WF, Kloepper JW. 1997. Temporal changes in the bacterial communities of soil, rhizosphere and endorhiza associated with field grown cucumber (Cucumis sativus, L.). Can J Microbiol 34:210-23.

Milner JL, Raffel SJ, Lethbridge BJ, Handelsman J. 1995. Culture conditions that influence accumulation of zwittermicin A by Bacillus cereus UW85. Appl Microbiol Biotechnol 43:685-91.

Milner JL, Silo-Suh L, Lee JC, He H, Clardy J, Handelsman J. 1996. Production of kanosamine by Bacillus cereus UW85. Appl Environ Microbiol 62:3061-5.

Nakayama T, Homma Y, Hashidoko Y, Mizutani J, Tahara S. 1999. Possible role of xanthobaccins produced by Stenotrophomonas sp. strain SB-K88 in suppression of sugar beet damping-off disease. Appl Environ Microbiol 65:4334-9.

Nalisha I, Muskhazli M, Nor Farizan T. 2006. Production of bioactive compounds by Bacillus subtilis against Sclerotium rolfsii. Malay Microbiol 2:19-23.

Phosri C, Rodriguez A, Sanders IR, Jeffries P. 2010. The role of mycorrhizas in more sustainable oil palm cultivation. Agric Ecosyst Environ 135:187-93.

Raaijmakers JM, Vlami M, de Souza JT. 2002. Antibiotic production by bacterial biocontrol agents. Antonie Leeuwenhoek 81:537-47.

Reimann S. 2005. The interrelationship between rhizobacteria and arbuscular mycorrhizal fungi and their importance in the integrated management of nematodes and soil borne pathogens. [Dissertation for $\mathrm{PhD}$ ]. Germany: Universitat zu Bonn. pp 91.

Sapak Z, Meon S, Mior Ahmad ZA. 2008. Effect of endophytic bacteria on growth and suppression of Ganoderma infection in oil palm. Int J Agri Biol 10:127-32.

Singh PP, Shin YC, Park CS, Chung YR. 1999. Biological control of Fusarium wilt of cucumber by chitinolytic bacteria. Phytopathol 89:92-9.

Souto GI, Correa OS, Montecchia MS, Kerber NL, Pucheu NL, Bachur M, Garcia AF. 2004. Genetic and functional characterization of a Bacillus sp. Strain excreting surfacting and antifungal metabolites partially identified as iturins-like compounds. J Appl Microbiol 97:1247-1256. 
Sundram S, Abdullah F, Ahmad ZAM, Yusuf UK. 2008. Efficay of single and mixed treatments of Trichoderma harzianum as biocontrol agents of Ganoderma basal stem rot in oil palm. J Oil Palm Res 20:470-83.

Treu R. 1998. Macro fungi in oil palm plantations of South East Asia. J Gen Mycol 12:10-4.

Velmurugan N, Choi MS, Han SS, Lee YS. 2009. Evaluation of antagonistic activities of Bacillus subtilis and Bacillus licheniformis against wood-staining fungi: in vitro and in vivo experiments. J Microbiol 47:385-92.
Weller DM. 1988. Biological control of soilborne plant pathogens in the rhizosphere with bacteria. Annu Rev Phytopathol 26:379-407.

Xavier LCJ, Germida JL. 2003. Bacteria associated with Glomus clarum spores influence mycorrhizal activity. Soil Biol Biochem 35:471-8.

Yang CH, Crowley DE. 2000. Rhizosphere microbial community structure in relation to root location and plant iron status. Appl Environ Microbiol 66:345-51. 